\title{
Foraging behaviour of Weddell seals, and its ecological implications
}

Accepted: 12 May 2001 / Published online: 30 June 2001

(C) Springer-Verlag 2001

\begin{abstract}
Time-depth recorder data of eight adult Weddell seals (Leptonychotes weddellii) provided simultaneous dive records over 8 days in the Drescher Inlet, eastern Weddell Sea coast, in February 1998. The seals primarily foraged within two depth layers, these being from the sea surface to $160 \mathrm{~m}$ where temperature and salinity varied considerably, and near the bottom from 340 to $450 \mathrm{~m}$ where temperature was lowest and salinity highest. While both pelagic and benthic diving occurred during daylight, the seals foraged almost exclusively in the upper water column at night. Trawling during daytime confirmed that Pleuragramma antarcticum were by far the most abundant fish both in the pelagial and close to the bottom. Pelagic night hauls at $110-170 \mathrm{~m}$ depth showed highly variable biomass of $P$. antarcticum. The temporal changes in the local abundance of $P$. antarcticum, particularly in the pelagial, may explain the trends in the seals' pelagic and benthic foraging activities. This study describes the jaw movements of a hunting seal, which are presumably indicative of feeding events. Trophic links from the Weddell seal to fish, zooplankton and krill, Euphausia superba, are discussed.
\end{abstract}

\section{Introduction}

Research projects that focus on the ecology of the Antarctic sea-ice zone require investigations on the

This paper presents results of the Midterm Symposium of the SCAR programme "Ecology of the Antarctic Sea Ice Zone" (EASIZ). The manuscript was edited by W. Arntz and A. Clarke.

J. Plötz $(\bowtie) \cdot$ H. Bornemann · R. Knust · A. Schröder Alfred-Wegener-Institut für Polar- und Meeresforschung, Postfach 120161, 27515 Bremerhaven, Germany

E-mail: jploetz@awi-bremerhaven.de

M. Bester

Mammal Research Institute, Department of Zoology \& Entomology, University of Pretoria, Pretoria 0002, South Africa trophic links between top predators and their prey. The Weddell seal is adapted to exploit coastal shelf waters, which are largely covered by fast ice for most of the year. Complementary fishery and hydrographic data from locations where Weddell seals are diving and foraging are sparse. Pleuragramma antarcticum is the dominant pelagic fish in the Ross Sea (e.g. DeWitt 1970) and Weddell Sea (Hubold 1985) and, consequently, the main prey for Weddell seals in the Ross Sea (e.g. Castellini et al. 1984; Burns et al. 1998) and Weddell Sea (Plötz 1986). The present paper attempts to relate the diving behaviour of the Weddell seal both to the vertical distribution of its principal prey and to local hydrographic processes in a fast-ice environment that is characterised and strongly influenced by the seasonal ice break-up, particularly during late summer.

\section{Materials and methods}

During the EASIZ (II) Weddell Sea cruise of RV Polarstern, a joint seal-fisheries project was carried out from 26 January to 25 February 1998 at Drescher Inlet $\left(72^{\circ} 52^{\prime} \mathrm{S}, 19^{\circ} 26^{\prime} \mathrm{W}\right)$, a $25-\mathrm{km}$-long and 1 - to $2-\mathrm{km}$-wide crack in the Riiser Larsen Ice Shelf. The sea bed under the ice shelf extends over $100 \mathrm{~km}$ to the nearest grounding line of Dronning Maud Land (Schenke et al. 1998). According to bathymetric surveys of RV Polarstern (Graffe and Niederjasper 1997), the depth of the seafloor inside the inlet ranges from $430 \mathrm{~m}$ in the inner section to $380 \mathrm{~m}$ over a central $6-\mathrm{km}$-wide bank, and to $520 \mathrm{~m}$ at the inlet mouth. The depth outside the inlet gradually increases, reaching the $600-\mathrm{m}$ isobath about $2 \mathrm{~km}$ distant from the inlet mouth.

\section{Recording and processing of seal data}

The seal studies were conducted from a camp on the ice shelf. Twenty-five Weddell seals were equipped with time-depth recorders (TDRs) (Driesen and Kern, Bad Bramstedt, Germany). Strong gales and sea swell induced ice break-up, which was most intensive from 13 to 16 February. Over a few days, the fast ice progressively retreated into the inlet so that the recapture of 11 instrumented seals was impossible. For this study, the data sets of eight TDRs were selected as they provided simultaneous records which allowed a direct comparison of the diving and haul-out patterns of eight seals (three males, five females) over a period of 8 days (9-17 